A N N A L ES

UNIVERSITATIS MARIAE CURIE-SKŁODOWSKA

LUBLIN - POLONIA

VOL. LXII, 2

SECTIO G

2015

MACIEJ JAROTA

\title{
Funkcja ochronna prawa pracy na przykładach wybranych regulacji państw europejskich
}

The Protective Function of Labour Law Regulations on Examples of Selected European Countries

I.

Żeby przedstawić wybrane przykłady instytucji ochrony pracownika jako strony słabszej stosunku pracy $\mathrm{w}$ systemach prawa państw europejskich, należy tytułem wprowadzenia wyjaśnić istotę funkcji ochronnej prawa pracy, chociaż trzeba zaznaczyć, że jest ona pojmowana bardzo szeroko, co może utrudniać jej poznanie i przeanalizowanie ${ }^{1}$. W polskim piśmiennictwie traktuje się ją jako najważniejszą, charakterystyczną dla stosunku pracy cechę wynikającą zarówno z norm prawa pracy zakodowanych w przepisach aktów normatywnych, jak i ze specyficznego mechanizmu ich oddziaływania ${ }^{2}$. Wpływ funkcji ochronnej prawa pracy dotyczy sytuacji prawnej pracownika zdefiniowanej w art. 2 ustawy z dnia 26 czerwca 1974 roku - Kodeks pracy ${ }^{3}$, który dzięki niej jest, jako strona znajdująca się w gorszej socjalnie i ekonomicznie pozycji od pracodawcy, uprzywilejowany pod wieloma względami ${ }^{4}$. Przede wszystkim funkcja ta ma na celu zapobieganie wyzyskowi osoby świadczącej pracę 5 . Jej wyrazem są regulacje prawne

1 Zob. A. Sobczyk, Różnicowanie praw (ochrony) zatrudnionych - wybrane kryteria i ich ocena, [w:] Funkcja ochronna prawa pracy a wyzwania współczesności, pod red. M. Bosaka, Warszawa 2014, s. 1.

2 T. Liszcz, Ogólna charakterystyka prawa pracy, [w:] Zarys prawa pracy, pod red. R. Borek-Buchajczuk [et al.], Lublin 2005, s. 22.

3 Dz.U. z 1974 roku, nr 24, poz. 141 z późn. zm.

4 T. Liszcz, Prawo pracy, Lublin 2008, s. 26-27.

5 M. Gersdorf, Pojęcie, przedmiot i właściwości prawa pracy, [w:] Prawo pracy w pytaniach i odpowiedziach, pod red. M. Gersdorf, K. Rączki, Warszawa 2004, s. 60. 
dotyczące: bezpieczeństwa i higieny pracy oraz związanej z tym ochrony zdrowia i życia pracownika ${ }^{6}$; ochrony pracy kobiet i młodocianych ${ }^{7}$; czasu pracy, w tym konstytucyjnego prawa do urlopu ${ }^{8}$ zagwarantowanego w art. 66 ust. 2 Konstytucji RP z dnia 7 kwietnia 1997 roku9; ochrony wynagrodzenia za pracę, w szczególności zakazu zrzekania się prawa do wynagrodzenia za pracę przez pracownika i ograniczenia dopuszczalności potrąceń z wynagrodzenia. Jej przejawem są także konstrukcje prawne dotyczące rozwiązywania umowy o pracę $^{10}$ ze wskazaniem, że pracownikowi przysługuje luz decyzyjny w zakresie wypowiadania umowy o pracę, z kolei pracodawca zasadniczo przy wypowiadaniu umowy o pracę na czas nieokreślony jest obowiązany uzasadnić wypowiedzenie i skonsultować swoje działania ze związkami zawodowymi w rozumieniu art. $30 \S 4$ i art. $38 \S 1$ k.p. Ponadto funkcję ochronną powinna realizować m.in. Państwowa Inspekcja Pracy sprawująca nadzór ${ }^{11}$ nad przestrzeganiem prawa pracy przez pracodawców, której uprawnienia w tym zakresie wprowadzono ustawą z dnia 13 kwietnia 2007 roku o Państwowej Inspekcji Pracy ${ }^{12}$. Na wyjątkową uwagę zasługuje zasadniczy mechanizm prawny - forma działania norm semiimperatywnych ${ }^{13}$, według której zgodnie z art. $18 \S 1 \mathrm{i}$ art. $18 \S 2$ k.p. strony stosunku pracy mogą ustalić postanowienia ich obowiązujące, korzystniejsze dla pracownika niż regulacje prawne wyższego rzędu, natomiast mniej korzystne dla pracownika postanowienia niż przepisy prawa pracy są z mocy prawa nieważne. Nie oznacza to, że wątpliwości interpretacyjne związane z językowym brzmieniem normy prawnej należy rozstrzygać na korzyść pracownika ${ }^{14}$. Ponadto w doktrynie podkreśla się znaczenie

6 W Polsce ochronie praw pracowniczych, m.in. w zakresie bhp, służą także przepisy prawa karnego przez stosowanie sankcji za popełnienie czynu zabronionego z art. 220 ustawy z dnia 6 czerwca 1997 roku - Kodeks karny (Dz.U., nr 88, poz. 554) lub wykroczenia z art. 283 k.p. Zob. szerzej na ten temat: D. Habrat, Prawnokarna ochrona praw pracownika zwiazana z bezpieczeństwem i higiena pracy, [w:] Funkcja ochronna prawa pracy..., s. 189-199.

7 Zob. szerzej na ten temat: I.A. Wieleba, Szczególna ochrona zdrowia pracowników młodocianych-zagadnienia wybrane, [w:] Funkcja ochronna prawa pracy..., s. 71-84.

8 Zob. szerzej na ten temat: W. Dyląg, Prawo do odpoczynku jako przejaw funkcji ochronnej prawa pracy, [w:] Funkcja ochronna prawa pracy..., s. 27-38.

9 Dz.U. z 1997 roku, nr 78, poz. 483 z późn. zm.

10 T. Liszcz, Prawo pracy, s. 27.

11 Regulacje dotyczące nadzoru PIP stanowią przykład norm prawnych i mechanizmów ich działania, w których przejawia się funkcja ochronna prawa pracy. Nie zawsze jednak w praktyce konstrukcje prawne zapewniające inspektorowi pracy podjęcie stosownych czynności są właściwie realizowane, tym samym nie zapewniają w pełni ochrony pracownikom. Zob. np. Co powinien robić inspektor pracy, a czego nie robi? Nie chce czy nie może?, www.siprp.pl/co-powinien-robicinspektor-pracy-a-czego-nie-robi-nie-chce-czy-nie-moze [data dostępu: 20.02.2015].

12 Dz.U. z 2007 roku, nr 89, poz. 589 z późn. zm.

13 A.M. Świątkowski, Polskie prawo pracy, Warszawa 2010, s. 32.

14 T. Liszcz, Prawo pracy, s. 27; L. Kaczyński, Zasada uprzywilejowania pracownika w świetle kodeksu pracy, „Państwo i Prawo” 1984, z. 8, s. 60-61. 
tzw. ochrony procesowej pracownika ${ }^{15}$, którą sprawuje organ ochrony prawnej, jakim jest Sąd Pracy ${ }^{16}$.

W Europie funkcję ochronną prawa pracy określa się jako regulacje prawne i mechanizmy uprzywilejowania osób pozostających w stosunku pracy, szczególnie ze względu na sytuację faktyczną, w jakiej się znajdują, np. wiek (tzw. protection law) oraz konstrukcje prawne sprowadzające się do zapobiegania nieuzasadnionemu rozwiązywaniu umowy o pracę z pracownikiem przez pracodawcę (tzw. job security $)^{17}$. W niniejszej analizie zostanie przedstawiona funkcja ochronna prawa pracy w trzech aspektach: prawa pracowników do urlopu wypoczynkowego; ochrony osób w wieku poniżej 18. roku życia świadczących pracę; sytuacji prawnej pracownika, z którym pracodawca zamierza rozwiązać umowę o pracę w drodze wypowiedzenia, z ograniczeniem się do wybranych instytucji: Grecji, Hiszpanii, Łotwy, Niemiec, Szwecji, Wielkiej Brytanii i Włoch. Wyżej wymienione zagadnienia, dotyczące ingerowania w stosunek pracy w celu ochrony pracownika, zostaną opisane w sposób podstawowy.

II.

We Włoszech prawo pracowników do urlopu wypoczynkowego wprowadza art. 36 ustawy zasadniczej. Długość urlopu determinują porozumienia zbiorowe, jednak zgodnie $\mathrm{z}$ art. 10 dekretu 66/2003 $3^{18}$ minimalny okres urlopu wynosi 4 tygodnie w skali roku. Niektóre porozumienia gwarantują pracownikom z 10-letnim stażem pracy dodatkowy dzień urlopu, natomiast pracownikom z 18-letnim stażem odpowiednio zwiększenie liczby przysługujących dni urlopu o $6 \mathrm{dni}^{19}$. W Szwecji odnośnie do prawa do urlopu wypoczynkowego wprowadzono zasadę, zgodnie z którą pracownikowi przysługuje możliwość wykorzystania urlopu wypoczynkowego w wymiarze 25 dni rocznie za wynagrodzeniem, o ile przepracował on w całości poprzedni rok, liczony od 1 kwietnia do 31 marca $^{20}$. W Grecji pracownikom przysługuje prawo do urlopu wypoczynkowego w wymiarze 20 dni, o ile świadczyli oni pracę przez co najmniej 12 miesięcy w ostatnich dwóch latach albo w ciągu trzech lat, w każdym $\mathrm{z}$ tych lat minimum 4 miesiące $\mathrm{w}$ jednym

15 M. Gersdorf, op. cit., s. 62.

16 K.W. Baran, Procesowe prawo pracy. Wzory pism, Warszawa 2013, s. 37-38.

17 A. Adlecreutz, B. Nyström, Labour Law in Sweden, Alphen aan den Rijn 2010, s. 112, 134; I. Tare, Labour Law in Latvia, Alphen aan den Rijn 2011, s. 88, 94; M. Alonso Olea, F . RodríguezSañudo, Labour Law in Spain, Alphen aan de Rijn 2010, s. 83, 95.

18 Attuazione delle direttive 93/104/CE e 2000/34/CE concernenti taluni aspetti dell'organizzazione dell'orario di lavoro, www.camera.it/parlam/leggi/deleghe/03066dl.htm [data dostępu: 31.03.2015].

19 T. Treu, Labour Law in Italy, Alphen aan de Rijn 2011, s. 84-85.

20 A. Adlecreutz, B. Nyström, op. cit., s. 119. 
zakładzie pracy. Powyższe kryteria są jednakowe dla wszystkich pracowników, niezależnie od wypłaty wynagrodzenia pracownikowi, szczególnie w okresie urlopu. Wskazuje się, że jeżeli pracodawca nie ureguluje zobowiązania w formie wynagrodzenia $\mathrm{w}$ stosunku do pracownika $\mathrm{w}$ terminie, pracownik może domagać się odszkodowania i odsetek od dnia, w którym wynagrodzenie powinno być zapłacone. Wszelkie roszczenia $\mathrm{z}$ tego tytułu $\mathrm{w}$ stosunku do pracodawcy przedawniają się z upływem 5 lat od dnia wymagalności świadczenia ${ }^{21}$.

W Republice Federalnej Niemiec prawo pracownika do corocznego urlopu wypoczynkowego gwarantuje ustawa z 1963 roku o urlopach. Pierwotnie ten akt prawny zakładał, że pracownikowi przysługuje 18 dni roboczych urlopu, co w 1994 roku zostało zmienione przez zagwarantowanie pracownikowi możliwości wykorzystania w każdym roku 24 dni roboczych urlopu ${ }^{22}$. Za okres urlopu przysługuje pracownikowi wynagrodzenie w wysokości równowartości średniego wynagrodzenia otrzymywanego przez pracownika w ciągu 13 tygodni poprzedzających pierwszy dzień urlopu. Art. 19 ustawy o urlopach zapewnia minimalny roczny urlop dla pracowników młodszych niż 16 lat wynoszący 30 dni roboczych, pracowników od 16. do 17. roku życia -27 dni roboczych i pracowników między 17. a 18. rokiem życia - 25 dni roboczych. Regulacja zawarta w art. 125 Kodeksu ochrony socjalnej nr IX przewiduje dodatkowy urlop 5 dni roboczych dla pracowników niepełnosprawnych. W części zakładów pracy długość urlopu wypoczynkowego określają odmiennie na korzyść pracowników układy zbiorowe pracy ${ }^{23}$.

III.

We Włoszech dzieci w wieku poniżej 15 lat mogą świadczyć pracę wyjątkowo w ramach realizacji obowiązku szkolnego, maksymalnie w wymiarze 35 godzin tygodniowo, przy 7-godzinnej dobowej normie czasu pracy i 30 dniach urlopu wypoczynkowego. W stosunku do pracowników młodocianych między 15 . a 18. rokiem życia znajduje zastosowanie maksymalna tygodniowa norma czasu pracy -40 godzin, dobowa -8 godzin, przy zachowaniu prawa pracownika do 20-dniowego urlopu wypoczynkowego ${ }^{24}$.

$\mathrm{Na}$ Łotwie pracownicy poniżej 18. roku życia dzielą się na dwie grupy, tj. dzieci (osoby od 13. do 15. roku życia) i młodocianych (osoby w wieku 15-

${ }^{21}$ Ibidem, s. 88.

22 Do dni roboczych w Niemczech nie zalicza się sobót, niedziel i świąt. Zob. M. Weiss, M. Schmidt, Labour Law in Germany, Alphen aan den Rijn 2008, s. 103.

${ }_{23}$ Ibidem.

24 T. Treu, op cit., s. 60. Odmiennie jest w Szwecji, w której dzieci poniżej 16. roku życia, które nie ukończyły szkoły, zasadniczo nie mogą świadczyć pracy. Zob. A. Adlecreutz, B. Nyström, op. cit., s. 88. 
18 lat) ${ }^{25}$. Na podstawie art. 132 ust. 2 i 3 Kodeksu pracy dzieci nie mogą wykonywać obowiązków pracowniczych dłużej niż przez 2 godziny dziennie i 10 godzin tygodniowo w roku szkolnym lub dłużej niż przez 4 godziny dziennie i 20 godzin tygodniowo $\mathrm{w}$ okresie wakacji ${ }^{26}$. Młodocianego pracownika obowiązuje maksymalna dobowa norma czasu pracy wynosząca 7 godzin, przy tygodniowym wymiarze czasu pracy nieprzekraczającym 35 godzin $^{27}$. Zgodnie z art. 37 Kodeksu pracy zabrania się zatrudniania młodocianych i dzieci do pracy w szczególnych warunkach, które są związane ze zwiększonym ryzykiem dla ich bezpieczeństwa, zdrowia, moralności i rozwoju. Rada Ministrów określa charakter pracy, której świadczenie przez osoby poniżej 18. roku życia jest zabronione. Przedmiotową kwestię reguluje Regulamin NP. 206 z maja 2006 roku. Z młodocianym i dzieckiem stosunek pracy może być nawiązany po uprzednim badaniu lekarskim i powiadomieniu jednego z rodziców o zagrożeniach związanych ze stanowiskiem pracy, co nie wyklucza późniejszego obowiązku przeprowadzania regularnych badań medycznych raz w roku. Specjalne środki ochrony młodych pracowników dotyczą wprowadzonego zakazu zatrudniania ich w godzinach nadliczbowych i w porze nocnej ${ }^{28}$. Jeżeli młodociany lub dziecko wykonuje obowiązki pracownicze, które zagrażają zdrowiu, moralności lub bezpieczeństwu bądź negatywnie wpływają na jego rozwój i edukację, na podstawie art. 115 Kodeksu pracy rodzice, opiekunowie lub inspektorzy pracy mogą zwrócić się na piśmie do pracodawcy z wnioskiem o rozwiązanie stosunku pracy. Pracodawca po otrzymaniu wniosku ma obowiązek w terminie 5 dni rozwiązać umowę o pracę z pracownikiem i zapłacić mu właściwe odszkodowanie ${ }^{29}$.

W Hiszpanii młodociani w wieku od 16 do 18 lat mogą zawrzeć umowę o pracę za zezwoleniem jednego z rodziców lub - w razie ich braku - za zgodą opiekuna prawnego. Młodociani pracownicy mają możliwość autonomicznego zawarcia umowy o pracę bez jakiejkolwiek akceptacji osób trzecich, jeżeli pozostają $\mathrm{w}$ związku małżeńskim lub za wiedzą i aprobatą rodziców mieszkają poza miejscem ich zamieszkania ${ }^{30}$. Zabronione jest przez tego typu pracowników wykonywanie prac wzbronionych ustalonych na podstawie porozumienia między Radą Ministrów a reprezentatywnymi organizacjami pracodawców i pracowników. Ponadto pracownicy młodociani nie mogą świadczyć pracy w porze nocnej

25 I. Tare, op. cit., s. 80.

26 www.lm.gov.lv/upload/legislation/leg_er_1.pdf [data dostępu: 31.03.2015].

27 W stosunku do pozostałych pracowników maksymalna dobowa norma czasu pracy wynosi 8 godzin, tygodniowa -40 godzin. Zob. I. Tare, op. cit., s. 78.

28 Ibidem, s. 94. Zakaz pracy w porze nocnej na Łotwie dotyczy też kobiet w ciąży, kobiet w okresie po urodzeniu dziecka do 1 roku i kobiet karmiących piersią, a także wszystkich pracowników, których dziecko jest w wieku do 3 lat, o ile pracownicy ci nie wyrażą na to zgody. Ibidem, s. 81 .

29 Ibidem, s. 94.

30 M. Alonso Olea, F . Rodríguez-Sañudo, op. cit., s. 58. 
między godz. 22.00 a 6.00, a maksymalna norma dobowa czasu ich pracy wynosi $8 \operatorname{godzin}^{31}$.

IV.

We Włoszech wypowiedzenie umowy o pracę zawartej na czas nieokreślony może nastąpić z uzasadnionych przyczyn, tj. na skutek naruszenia obowiązków pracowniczych lub ze względu na działalność produkcyjną bądź organizacyjną zakładu pracy. W piśmiennictwie podkreśla się, że powodem rozwiązania umowy o pracę tego rodzaju może być m.in.: nieuzasadniona nieobecność w pracy powyżej 4 dni, niesubordynacja pracownika, znaczące uszkodzenie mienia pracodawcy ${ }^{32}$. W Wielkiej Brytanii, na mocy ustawy o prawach pracowniczych z 1996 roku, pracodawca jest obowiązany sporządzić oświadczenie zawierające przyczynę rozwiązania każdej umowy o pracę z pracownikiem, na jego wniosek w terminie 14 dni od dnia otrzymania żądania w tym zakresie, jeżeli pracownik był u niego zatrudniony co najmniej 12 miesięcy ${ }^{33}$. W Grecji praca na podstawie art. 22 ustawy zasadniczej znajduje się pod ochroną prawa. Wyrazem funkcji ochronnej jest wiele ograniczeń ustawowych w zakresie przyczyn, które mogą stanowić przesłankę do rozwiązania umowy o pracę z pracownikami ${ }^{34}$, dlatego w praktyce działania pracodawcy są oceniane w pewnych sytuacjach jako czynności sprzeczne z prawem ${ }^{35}$.

$\mathrm{Na}$ Łotwie pracodawca przed złożeniem wypowiedzenia umowy o pracę zawartej na czas określony i nieokreślony pracownikowi reprezentowanemu przez związek zawodowy, powinien najpierw otrzymać zgodę odpowiedniego związku zawodowego. We wszystkich przypadkach pracodawca ma obowiązek poinformowania pracownika na piśmie o okolicznościach, które stanowią podstawę rozwiązania umowy o pracę ${ }^{36}$. Zgodnie z art. 101 Kodeksu pracy pracodawca może wypowiedzieć umowę o pracę na czas określony i nieokreślony na podstawie przyczyn związanych z zachowaniem i umiejętnościami pracownika oraz w związku z wystąpieniem innych powodów dotyczących ekonomicznych, organizacyjnych, technologicznych środków produkcji lub pozostałych środków przyrody wpływających na działalność przedsiębiorstwa ${ }^{37}$.

W niemieckiej literaturze prawa pracy podkreśla się, że pierwszy raz poważnie wzmocniono sytuację prawną pracownika w przypadku rozwiązania umowy

31 Ibidem, s. 95.

32 T. Treu, op. cit., s. 115, 116.

33 S. Hardy, Labour Law in Great Britain, Alphen aan de Rijn 2012, s. 181.

34 Zob. szerzej na temat przyczyn uprawniających do rozwiązania stosunku pracy z pracownikiem przez pracodawcę: T. Koniaris, Labour Law in Hellas, Alphen aan de Rijn 2002, s. 156.

35 Ibidem, s. 157.

36 I. Tare, op. cit., s. 88-90.

37 Ibidem, s. 90. 
o pracę przez określenie minimalnego okresu wypowiedzenia dla pracowników fizycznych - 2 tygodni, dla pracowników umysłowych - 6 tygodni ${ }^{38}$. W 1993 roku na podstawie art. $622 \S 1$ Kodeksu cywilnego zrównano sytuację prawną wszystkich pracowników, ustalając, że minimalny okres wypowiedzenia wynosi 4 tygodnie dla każdego pracownika, wydłużony po 2 latach pracy o 1 miesiąc, po 5 latach stażu pracy o 2 miesiące, po 8 latach o 3 miesiące, po 10 latach o 4 miesiące, po 12 latach o 5 miesięcy, po upływie 15 lat o 6 miesięcy, a po 20 latach o 7 miesięcy $^{39}$. Jednakże mechanizm przedłużenia okresu wypowiedzenia nie rozpoczyna się dopóki pracownik nie osiągnie wieku 25 lat, co zdaniem piśmiennictwa prawa pracy narusza zakaz dyskryminacji ze względu na wiek ${ }^{40}$ ujęty w dyrektywie 2002/73/WE Parlamentu Europejskiego i Rady z dnia 23 września 2002 roku zmieniającej dyrektywę Rady 76/207/EWG w sprawie wprowadzenia w życie zasady równego traktowania mężczyzn i kobiet w zakresie dostępu do zatrudnienia, kształcenia i awansu zawodowego oraz warunków pracy ${ }^{41}$.

W niemieckim prawie pracy przyjęto zasadę, zgodnie z którą wypowiedzenie jest nieuzasadnione, jeżeli nie zostały spełnione przesłanki wskazane w ustawie w momencie, w którym pracownikowi złożono oświadczenie o rozwiązaniu umowy o pracę w drodze wypowiedzenia ${ }^{42}$. Na podstawie art. $102 \S 1$ ustawy o pracy przed złożeniem wypowiedzenia umowy o pracę na czas nieokreślony pracodawca ma obowiązek zasięgnięcia opinii rady zakładowej dotyczącej zasadności wypowiedzenia. Pracodawca jest obowiązany poinformować radę zakładową m.in. o pracowniku, z którym rozwiązuje umowę o pracę i przyczynie jej rozwiązania. Przed rozwiązaniem umowy o pracę w drodze wypowiedzenia rada zakładowa w ciągu tygodnia może żądać złożenia wyjaśnień lub wyrazić sprzeciw wobec wypowiedzenia w formie pisemnej ${ }^{43}$. Podstawowym błędem pracodawców niemieckich w zakresie rozwiązywania stosunków pracy, na który wskazuje doktryna prawa pracy w oparciu o stanowisko judykatury Federalnego Sądu Pracy,

38 M. Weiss, M. Schmidt, op. cit., s. 123. Należy uznać, że okres wypowiedzenia jest wprowadzany w interesie zarówno pracownika, jak i pracodawcy. Pracownik może w tym czasie szukać nowej pracy, z kolei pracodawca ma możliwość znalezienia osoby na stanowisko pracy dotychczas zajmowane przez pracownika, któremu złożono wypowiedzenie. Zob. D. Dörre-Nowak, Ustanie stosunku pracy, [w:] Prawo pracy i ubezpieczeń społecznych, pod red. K.W. Barana [et al.], Warszawa 2013, s. 222. Stąd też nazywanie wzmocnieniem sytuacji prawnej wyłącznie pracownika za pomocą zmian w regulacjach niemieckiego prawa pracy przez ustalenie minimalnego okresu wypowiedzenia jest daleko idącym wnioskowaniem. Można tutaj raczej mówić o wzmocnieniu obu stron stosunku pracy, oczywiście zastanawiając się nad siłą tego wzmocnienia.

39 W trakcie okresu próbnego, który nie przekracza 6 miesięcy, okres wypowiedzenia wynosi 2 tygodnie (art. $622 \S 3$ Kodeksu cywilnego).

${ }^{40}$ M. Weiss, M. Schmidt, op. cit., s. 126-127.

41 Dz.Urz. WE L 269 z dnia 5 października 2002 roku.

42 Zob. M. Weiss, M. Schmidt, op. cit., s. 127-129.

43 Ibidem, s. 130. 
jest przytaczanie przyczyny wypowiedzenia umowy o pracę, która może wystąpić w przyszłości, lecz nie ma miejsca w chwili złożenia takiego wypowiedzenia pracownikowi ${ }^{44}$.

W Niemczech w układach zbiorowych pracy przewiduje się dodatkową ochronę stosunku pracy niektórych pracowników. Przykładowo nie można wypowiedzieć umowy o pracę na czas nieokreślony pracownikom zatrudnionym w zakładach pracy przemysłu metalurgicznego po osiągnięciu przez nich 53 lat życia oraz zakazane jest $\mathrm{w}$ ten sposób rozwiązywanie umowy o pracę z pracownikami umysłowymi, jeżeli przepracowali oni w sektorze publicznym 15 lat. W tym kontekście bardzo poważnie rozważa się w piśmiennictwie i judykaturze, czy przedmiotowe ustalenia stron są zgodne z zasadą niedyskryminowania pozostałych pracowników ${ }^{45}$.

\section{V.}

„Praca jest powinnością, czyli obowiązkiem człowieka, i to w wielorakim tego słowa znaczeniu. Jeśli praca - w wielorakim tego słowa znaczeniu - jest powinnością, czyli obowiązkiem, to jest ona równocześnie źródłem uprawnień po stronie człowieka pracującego" ${ }^{46}$. „Ostatecznym celem pracy [...] pozostaje zawsze sam człowiek", ponieważ ,praca jest dla człowieka, a nie człowiek dla pracy" ${ }^{47}$. Według Jana Pawła II oprócz pracodawcy również państwo powinno zagwarantować obiektywne uprawnienia pracownikowi. Przede wszystkim, zdaniem Papieża Polaka, należy zapewnić wszystkim pracownikom ochronę zdrowia i bezpieczeństwa w miejscu pracy, przy czym szczególną ochroną należy objąć pracowników wykonujących obowiązki wyjątkowego ryzyka ${ }^{48}$. W zasadzie praca jako atrybut człowieka związany z zaspokojeniem podstawowych jego potrzeb jest już wystarczającym powodem szczególnej ochrony pracownika, ale specyficzne ukształtowanie rynku pracy wspólnego dla państw rozwiniętych, na które oddziałuje wiele elementów - nie zawsze poprawnie funkcjonujących, jak m.in. konkurencyjność, wymiana informacji, stabilność gospodarcza wpływająca na reakcje podaży i popytu - doprowadza do konstatacji, że nie da się pozbawić państwa uprawnień interwencyjnych, zdając się wyłącznie na tzw. mechanizmy rynkowe ${ }^{49}$.

44 Na przykład wyrok Federalnego Sądu Pracy z dnia 27 lutego 1997 roku, 2 AZR 160/96, [w:] M. Weiss, M. Schmidt, op. cit., s. 133.

45 Ibidem, s. 135-138.

${ }^{46}$ Encyklika Ojca Świętego Jana Pawła II o pracy ludzkiej Laborem Exercens, [w:] Laborem Exercens. Powołany do pracy. Komentarz, pod red. J. Kruciny, Wrocław 1983, s. 47.

${ }^{47}$ Ibidem, s. 23.

48 T. Wyka, W poszukiwaniu aksjologii prawa pracy - o roli encykliki „Laborem exercens” Jana Pawta II, „Monitor Prawa Pracy” 2011, nr 9, s. 458.

49 Zob. szerzej na ten temat: M. Skąpski, Ochronna funkcja prawa pracy w gospodarce rynkowej, Kraków 2006, s. 110-121. 
W stosunkach pracy powinno się bardzo wszechstronnie rozważać wszystkie okoliczności, biorąc pod uwagę wartości wynikające ze społecznej solidarności i odpowiedzialności. Punktem wyjścia jest prymat pracy nad kapitałem, której nie da się oddzielić od człowieka, gdyż ma ona swój udział w jego godności ${ }^{50}$.

Wprowadzenie właściwych regulacji prawnych oraz mechanizmów ich funkcjonowania w zakresie ochrony pracownika jako strony słabszej stosunku pracy stanowi fundament względnej równowagi relacji między pracownikiem a pracodawcą i w konsekwencji umożliwia prawidłowy rozwój zakładów pracy. Dążenie do osiągnięcia wyników pracy nie uzasadnia wymagania od pracownika świadczenia pracy w taki sposób, który pozbawia go urlopu wypoczynkowego niezbędnego na regenerację organizmu. Negatywnie należy ocenić nawet nieświadome podjęcie próby narażenia na utratę zdrowia, szczególnie pracownika w młodym wieku u progu kariery zawodowej. Z kolei pracownikom o dłuższym stażu pracy zależy na stworzeniu warunków do podjęcia pracy u nowego pracodawcy w przypadku rozwiązania umowy o pracę przez dotychczasowego pracodawcę.

W Polsce należałoby rozważyć, czy istnieje konieczność poszerzenia uprawnień inspektorów pracy w zakresie ochrony sprawności i rozwoju pracowników młodocianych, np. w pewnej części korzystając z doświadczeń łotewskiego ustawodawcy, oraz czy aktualne regulacje prawne w tym aspekcie są wystarczające. Wydaje się, że warto precyzyjnie ustalić, jak często tego typu pracownicy powinni być poddawani okresowym badaniom lekarskim, gdyż z uwagi na brak doświadczenia, stopień dojrzałości fizycznej i psychicznej młodych osób wskazane jest kontrolowanie ich stanu zdrowia ${ }^{51}$ systematyczniej niż u pozostałych pracowników. Wymagałoby to dokonania zmian w rozporządzeniu Ministra Zdrowia i Opieki Społecznej z dnia 30 maja 1996 roku w sprawie przeprowadzania badań lekarskich pracowników, zakresu profilaktycznej opieki zdrowotnej nad pracownikami oraz orzeczeń lekarskich wydawanych do celów przewidzianych w Kodeksie pracy ${ }^{52}$. Na uwagę zasługuje również konstrukcja polegająca na znacznym wydłużeniu okresów wypowiedzenia umowy o pracę proporcjonalnie do stażu pracy, przyjęta w Republice Federalnej Niemiec, wzmacniająca zarówno sytuację prawną pracodawców, jak i pracowników. Pracownikowi z odpowiednio długim doświadczeniem świadczenia pracy w jednym zakładzie pracy w przypadku rozwiązania umowy o pracę trudno jest niezwłocznie znaleźć pracę u nowego pracodawcy, natomiast pracodawca potrzebuje czasami kilku tygodni czy miesięcy,

50 R. Marx, Kapitat. Mowa w obronie człowieka, przeł. J. Serafin, Kraków 2009, s. 232.

$51 \mathrm{Na}$ zaniedbania dotyczące ochrony pracowników młodocianych wskazuje Państwowa Inspekcja Pracy, która podkreśla, że jednym z najczęstszych uchybień pracodawców jest dopuszczenie do pracy pracownika młodocianego bez wstępnych i okresowych badań lekarskich. Zob. prawopl. pl/praca/aktualności/bhp/9414-pracodawcy-zaniedbują-obowiązki-w-zakresie-ochrony-zdrowiamłodocianych [data dostępu: 02.04.2015].

52 Dz.U. z 1996 roku, nr 69, poz. 332 z późn. zm. 
żeby przyjąć i przygotować odpowiednią osobę na stanowisko pracy zajmowane przez pracownika, któremu złożono wypowiedzenie. W niektórych przypadkach strony powinny zatem wypracować ustalenia dotyczące wprowadzenia dłuższych okresów wypowiedzenia niż te obowiązujące obecnie na podstawie art. $36 \S 1$ k.p.

\section{BIBLIOGRAFIA}

Adlecreutz A., Nyström B., Labour Law in Sweden, Alphen aan den Rijn 2010.

Alonso Olea M., Rodríguez-Sañudo F., Labour Law in Spain, Alphen aan de Rijn 2010.

Attuazione delle direttive 93/104/CE e 2000/34/CE concernenti taluni aspetti dell'organizzazione dell'orario di lavoro, www.camera.it/parlam/leggi/deleghe/03066dl.htm [data dostępu: 31.03.2015].

Baran K.W., Procesowe prawo pracy. Wzory pism, Warszawa 2013.

Co powinien robić inspektor pracy, a czego nie robi? Nie chce czy nie może?, www.siprp.pl/copowinien-robic-inspektor-pracy-a-czego-nie-robi-nie-chce-czy-nie-moze [data dostępu: 20.02.2015].

Dörre-Nowak D., Ustanie stosunku pracy, [w:] Prawo pracy i ubezpieczeń społecznych, pod red. K.W. Barana, K. Antonowa, B.M. Ćwiertniaka, D. Dörre-Nowak, K. Walczaka, Warszawa 2013.

Dyląg W., Prawo do odpoczynku jako przejaw funkcji ochronnej prawa pracy, [w:] Funkcja ochronna prawa pracy a wyzwania współczesności, pod red. M. Bosaka, Warszawa 2014.

Encyklika Ojca Świętego Jana Pawła II o pracy ludzkiej Laborem Exercens, [w:] Laborem Exercens. Powołany do pracy. Komentarz, pod red. J. Kruciny, Wrocław 1983.

Gersdorf M., Pojęcie, przedmiot $i$ właściwości prawa pracy, [w:] Prawo pracy w pytaniach i odpowiedziach, pod red. M. Gersdorf, K. Rączki, Warszawa 2004.

Habrat D., Prawnokarna ochrona praw pracownika zwiazana z bezpieczeństwem i higiena pracy, [w:] Funkcja ochronna prawa pracy a wyzwania współczesności, pod red. M. Bosaka, Warszawa 2014.

Hardy S., Labour Law in Great Britain, Alphen aan de Rijn 2012.

Kaczyński L., Zasada uprzywilejowania pracownika w świetle kodeksu pracy, „Państwo i Prawo” 1984, z. 8.

Koniaris T., Labour Law in Hellas, Alphen aan de Rijn 2002.

Liszcz T., Ogólna charakterystyka prawa pracy, [w:] Zarys prawa pracy, pod red. R. Borek-Buchajczuk, A. Kosut, J. Ligaj, T. Liszcz, M.R. Łysiak, W. Perdeusa, Lublin 2005.

Liszcz T., Prawo pracy, Lublin 2008.

Marx R., Kapitał. Mowa w obronie człowieka, przeł. J. Serafin, Kraków 2009.

prawopl.pl/praca/aktualności/bhp/9414-pracodawcy-zaniedbują-obowiązki-w-zakresie-ochronyzdrowia-młodocianych [data dostępu: 02.04.2015].

Skąpski M., Ochronna funkcja prawa pracy w gospodarce rynkowej, Kraków 2006.

Sobczyk A., Różnicowanie praw (ochrony) zatrudnionych - wybrane kryteria i ich ocena, [w:] Funkcja ochronna prawa pracy a wyzwania wspótczesności, pod red. M. Bosaka, Warszawa 2014.

Świątkowski A.M., Polskie prawo pracy, Warszawa 2010.

Tare I., Labour Law in Latvia, Alphen aan den Rijn 2011.

Treu T., Labour Law in Italy, Alphen aan de Rijn 2011.

Weiss M., Schmidt M., Labour Law in Germany, Alphen aan den Rijn 2008.

Wieleba I.A., Szczególna ochrona zdrowia pracowników młodocianych - zagadnienia wybrane, [w:] Funkcja ochronna prawa pracy a wyzwania współczesności, pod red. M. Bosaka, Warszawa 2014. 
www.lm.gov.lv/upload/legislation/leg_er_1.pdf [data dostępu: 31.03.2015]

Wyka T., W poszukiwaniu aksjologii prawa pracy - o roli encykliki „Laborem exercens” Jana Pawta II, „Monitor Prawa Pracy” 2011, nr 9.

\section{SUMARY}

The protective function of labour law is the most important feature of the employment relationship stemming from both labor law standards encoded in the provisions of normative acts, as well as the specific mechanism of their interaction. In Europe, the protective function of labour law is defined as the regulations and mechanisms privilege of remaining in employment, particularly in view of the factual situation in which they are located, for example age (the so called Protection law) and legal structures which boil down to prevent unjustified solve employment contract with the employee by the employer (the so-called job security). The study focuses on the presentation of three planes carrying out protective function of labour law: the right of workers to leave; protection of individuals under the age of 18 years performing work; the legal status of an employee, which the employer intends to terminate the employment contract by notice limited to the presentation of selected institutions: Greece, Spain, Latvia, Germany, Sweden, Great Britain and Italy.

Keywords: protective function; labour law; annual leave; adolescents; children; termination; years of service 